\title{
Aplikasi Pupuk Organik Pupuk Cair Dari Libah Tahu Berbantu Em-4 Terhadap Pertumbuhan Cabai Merah
}

\author{
Muhammad Rijal $^{1 *}$, Asrul Bin Syarif ${ }^{2}$, Cornelia Pary ${ }^{1}$, Sarti Imkari $^{1}$, Rosmawati ${ }^{1}$, \\ Heny Mutmainna ${ }^{1}$ \\ ${ }^{1}$ Dosen Pendidikan Biologi IAIN Ambon \\ ${ }^{2}$ Mahasiswa Pendidikan Biologi IAIN Ambon \\ *E-mail: rijal_rijal82@yahoo.co.id
}

\begin{abstract}
Abstrak: Penelitian ini bertujuan untuk mengetahui pengaruh pemberian EM-4 pada limbah cair tahu terhadap pertumbuhan tanaman cabai merah (Capsicum annuиm L.) dan untuk mengetahui seberapa besar pengaruh pemberian EM-4 pada limbah cair tahu terhadap pertumbuhan tanaman cabai merah. Jenis penelitian ini adalah penelitian eksperimen lapangan dengan menggunakan pendekatan deskriptif kuantitatif untuk menguji pengaruh pemberian EM-4 pada limbah cair tahu terhadap pertumbuhan tanaman cabai merah. Penelitian dilaksanakan selama dua bulan. Hasil penelitian menunjukkan bahwa secara deskriptif terdapat pengaruh pemberian EM-4 pada limbah cair tahu terhadap pertumbuhan tanaman cabai merah, yakni pada perlakuan pemberian EM-4 pada limbah cair tahu sebesar $2 \%\left(\mathrm{~V}_{1}\right)$ rata-rata memberian hasil yang tertinggi pada semua parameter yang diamati antara lain tinggi tanaman $40,9 \mathrm{~cm}$, diameter batang 0,46 cm, dan jumlah daun 68 helai. Besarnya pengaruh pemberian EM-4 pada limbah cair tahu terhadap pertumbuhan tanaman cabai merah berdasarkan analisis varian tidak memberikan pengaruh yang nyata pada tinggi tanaman karena nilai $\mathrm{F}_{\text {Hitung }}$ kelompok $(0,61)<\mathrm{F}_{\text {Tabel }}(5,14)$ dan nilai $\mathrm{F}_{\text {Hitung }}$ perlakuan $(1,23)<\mathrm{F}_{\text {Tabel }}(4,76)$ pada taraf signifikan $5 \%$. Pada diameter batang juga tidak memberikan pengaruh yang nyata karena nilai $\mathrm{F}_{\text {Hitung }}$ kelompok $(0,50)<\mathrm{F}_{\text {Tabel }}(5,14)$ dan nilai $\mathrm{F}_{\text {Hitung }}$ perlakuan $(3,05)<\mathrm{F}_{\text {Tabel }}(4,76)$ pada taraf signifikan 5\%. Demikian juga pada jumlah daun tidak memberikan pengaruh yang nyata

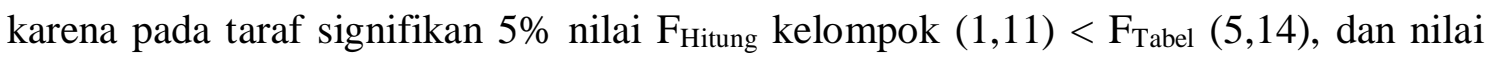
$\mathrm{F}_{\text {Hitung }}$ perlakuan $(1,13)<\mathrm{F}_{\text {Tabel }}(4,76)$.
\end{abstract}

\section{Kata Kunci: EM-4, Limbah Cair Tahu, Pertumbuhan, Cabai Merah.}

Abstract: This study aims to determine the effect of giving EM-4 to tofu liquid waste on the growth of red chilli (Capsicum annuum L.) and to determine how much influence the application of EM-4 to tofu wastewater on the growth of red chili plants. This type of research is a field experiment research using a quantitative descriptive approach to test the effect of EM-4 on tofu liquid waste on the growth of red chili plants. The research was conducted for two months. The results showed that descriptively there was an effect 
of giving EM-4 to tofu liquid waste on the growth of red chili plants, namely in the treatment of giving EM-4 to tofu liquid waste by $2 \%$ (V1) the average gave the highest yield on all parameters observed, among others, plant height $40.9 \mathrm{~cm}$, stem diameter 0.46 $\mathrm{cm}$, and the number of leaves 68 leaves. The magnitude of the effect of giving EM-4 to tofu liquid waste on the growth of red chili plants based on analysis of variance did not have a significant effect on plant height because the F value of the group $(0.61)<F_{\text {table }}$ (5.14) and the $F$ value of the treatment $(1.23))<F_{\text {table }}(4.76)$ at a significant level of $5 \%$. The stem diameter also did not have a significant effect because the value of the $\mathrm{F}_{\text {count }}$ of the group (0.50) $<\mathrm{F}$ Tabel $(5.14)$ and the $F$ value of the treatment $(3.05)<F_{\text {table }}$ (4.76) was at a significant level of 5\%. Likewise, the number of leaves did not have a significant effect because at a significant level of $5 \%$ the value of the $F_{\text {count }}$ of the group (1.11) $<F_{\text {table }}$ (5.14), and the value of $F_{\text {count }}$ of treatment $(1.13)<F_{\text {table }}(4.76)$.

\section{Keywords: EM-4, Tofu Liquid Waste, Growth, Red Chili.}

Cabai merah mengandung berbagai macam senyawa yang berguna bagi kesehatan manusia. Kandungan vitamin dalam cabe adalah A dan $\mathrm{C}$ serta mengandung minyak atsiri, yang rasanya pedas dan memberikan kehangatan bila kita gunakan untuk rempahrempah (bumbu dapur). Cabai merah mengandung anti oksidan yang berfungsi untuk menjaga tubuh dari radikal bebas. Radikal bebas yaitu suatu keadaan dimana suatu molekul kehilangan atau kekeurangan elektron, sehingga elektron tersebut menjadi tidak stabil dan selalu berusaha mengambil elektron dari sel-sel tubuh kita yang lainnya. Kandungan terbesar anti oksidan dalam cabai terdapat pada cabai hijau. Cabai juga mengandung Lasparaginase dan Capsaicin yang berperan sebagai zat anti kanker (Hadiyanto I., 2005)

Cabai merah (Capsicum annuum L.) banyak dibudidayakan oleh petani Indonesia selain karena manfaatnya bagi kesehatan juga karena cabai merah memiliki harga jual yang cukup tinggi (Prajanata F., 2007). Cabai menempati urutan paling atas diantara delapan belas jenis sayuran komersial yang dibudidayakan di Indonesia selama beberapa tahun teakhir ini. Oleh karena itu permintaan cabai merah cenderung meningkat tiap tahunnya. berdasarkan pemantauan harga disejumlah pasar terhadap komoditas cabai. Harga cabai merah keriting naik 25 persen dari Rp 40.000/kg menjadi Rp 50.000/kg, cabai merah besar naik 50 persen dari Rp 40.000/kg kini menjadi Rp 60.000/kg. Hal yang sama juga berlaku untuk cabai rawit yang naik 33 persen dari semula $R p$ 60.000/kg menjadi Rp 80.000/kg. Permintaan akan cabai yang meningkat dari waktu kewaktu ini menyebabkan cabai dapat diandalkan sebagai komoditas ekspor nonmigas. Hal ini terbukti dari enam besar komoditas sayuran segar yang diekspor (seperti bawang merah, tomat, kentang, kubis dan wortel) cabai termasuk salah satunya. 
Bertanam cabai dihadapkan dengan berbagai masalah (resiko) diantaranya: teknis budidaya, kekahatan hara dalam tanah, serangan hama dan penyakit. Maka dari itu perlu dukungan teknologi budidaya intensif baik itu terkait dengan pemupukan, proses pengolahan lahan, pemeliharaan, maupun penerapan-penerapan teknologi tepat guna sederhana dalam membudidayakannya. Pemberian unsur hara yang tepat sesuai dengan kebutuhan, waktu tanam dan penempatan hara pada daerah serapan akar juga menjadi pendukung dalam kudidaya tanaman cabai. Salah satu cara untuk meningkatkan produksi cabai besar sekaligus menanggulangi banyaknya permintaan masyarakat tersebut adalah dengan manajemen pemupukan yang menjadi bagian dari intensifikasi pertanian (Sunaryono, 2003). Pemupukan merupakan salah satu cara untuk memenuhi ketersediaan unsur hara dalam tanah yang akan dimanfaatkan oleh tanaman untuk pertumbuhan dan perkembangannya. Terdapat dua jenis pupuk, yaitu pupuk organik dan pupuk anorganik.

Pupuk organik adalah pupuk dengan bahan baku utama sisa makhluk hidup, seperti kotoran hewan, sisa tumbuhan, atau limbah rumah tangga yang telah mengalami proses pembusukan oleh mikroorganisme pengurai. Pupuk organik disamping berpengaruh terhadap pasokan hara tanah juga tidak kalah pentingnya terhadap sifat fisik, biologi dan kimia tanah. Pupuk anorganik adalah pupuk yang dibuat dengan proses fisika, kimia atau biologi. Pada umumnya pupuk anorganik dibuat oleh pabrik dan bahan yang digunakan berbeda-beda tergantung kandungan yang diinginkan (Nurbaiti dkk, 2017).

Peranan pupuk organik terhadap sifat fisik tanah yaitu mampu membentuk agregat tanah yang mempunyai peran sebagai bahan perekat antar partikel tanah untuk menjadi agregat tanah, sehingga pupuk organik penting untuk pembentukan struktur tanah. Pengaruh lain dari pupuk organik yaitu mampu meningkatkan porositas tanah. Porositas tanah adalah ukuran yang menunjukkan bagian tanah yang tidak terisi bahan padat tanah yang terisi oleh udara dan air. Dengan adanya porositas tanah ini, maka tanaman akan mendapat suplay air yang baik.

Secara biologi, pupuk organik adalah sumber utama energi atau menjadi bahan makanan bagi aktivitas jasad mikro tanah. Penambahan pupuk organik mendorong pembiakan jasad renik dan meningkatkan ketersediaan unsur hara tanaman, baik unsur hara makro maupun unsur hara mikro. Selain pengaruh fisik dan biologi, pupuk organik juga berpengaruh terhadap kimia tanah yaitu berfungsi sebagai penyuplai hara seperti nitrogen, fosfor dan kalium, juga mudah melepaskan hara tersebut untuk dipakai oleh tanaman.

Limbah cair tahu merupakan salah satu jenis pupuk organik sebagai hasil buangan dari industri tahu. Pada banyak penelitian ilmiah, telah dibuktikan bahwa pengaplikasian limbah cair tahu sebagai pupuk organik cair (POC) dapat memberikan dampak yang baik pada pertumbuhan tanaman. Penggunaan limbah cair tahu sebagai pupuk organik merupakan salah satu alternatif. Limbah cair tahu didapat dari hasil samping pembuatan tahu. Terdapat beberapa pabrik tahu di Kota Ambon, baik skala kecil maupun menengah 
dan menghasilkan limbah tahu yang dapat dimanfaatkan sebagai pupuk organik cair untuk budidaya pertanian, termasuk tanaman cabai merah (Capsicum annuиm L.).

Namun dalam penelitian ini, limbah cair tahu akan diberi EM-4 (Effective Microorganisme 4) untuk melihat pengaruhnya terhadap pertumbuhan tanaman cabai merah. EM-4 merupakan kultur campuran dalam medium cair berwarna coklat kekuningan, berbau asam dan terdiri dari mikroorganisme yang menguntungkan bagi kesuburan tanah. Diharapkan dengan adanya penambahan EM-4 pada limbah cair tahu, akan memberikan pengaruh yang signifikan bagi pertumbuhan tanaman cabai merah, sehingga hasil penelitian ini dapat memberikan rekomendasi kepada para petani cabai merah untuk menggunakan limbah cair tahu sebagai pupuk organik cair dengan penambahan EM-4.

\section{METODE PENELITIAN}

Jenis penelitian ini adalah penelitian eksperimen lapangan dengan menggunakan pendekatan deskriptif kuantitatif untuk menguji pengaruh pemberian EM-4 (Effective Microorganisme) pada limbah cair tahu terhadap pertumbuhan tanaman cabai merah (Capsicum annuиm L.). Penelitian dilaksanakan selama 2 bulan, yakni dimulai dari bulan Januari 2020 sampai dengan Februari 2020. Objek dalam penelitian ini adalah bibit tanaman cabai berumur 2 minggu sebanyak 12 tanaman.

Variabel yang digunakan dalam penelitian ini adalah: Variabel bebas (x) dalam penelitian ini adalah pemberian EM-4 (Effective Microorganisme) pada limbah cair tahu yang terdiri dari empat perakuan, yaitu: V0 (Kontrol), V1 (EM-4 2\%), V2 (EM-4 4\%), dan V3 (EM-4 6\%). Variabel terikat (y) yaitu pertumbuhan tanaman cabai merah (Capsicum annuиm L.), dengan indikator pengamatan meliputi tinggi tanaman, jumlah daun dan diameter batang.

Penelitian ini dilaksanakan dalam bentuk Rancangan Acak Kelompok (RAK) dengan perlakuan berbagai konsentrasi pemberian EM-4. Percobaan terdiri dari empat perlakuan dengan 3 kelompok, sehingga secara keseluruhan terdapat 12 unit percobaan. Setiap unit terdiri dari 1 tanaman, sehingga secara keseluruhan terdapat 12 tanaman, namun untuk mengantisipasi adanya kerusakan tanaman atau mati, maka peneliti perlu menyiapkan 24 tanaman.

Tabel 1. Desain Penelitian

\begin{tabular}{|c|c|c|c|c|c|}
\hline \multirow{2}{*}{ Perlakuan } & \multicolumn{3}{|c|}{ Kelompok } & \multirow{2}{*}{ Total (Y) } & \multirow{2}{*}{$\operatorname{Rerata}(\overline{\mathbf{Y}})$} \\
\hline & I & II & III & & \\
\hline V0 & V0.1 & V0.2 & V0.3 & Y.V0 & $\bar{Y} . \mathrm{V} 0$ \\
\hline V1 & V1.1 & V1.2 & V1.3 & Y.V1 & $\bar{Y} . \mathrm{V} 1$ \\
\hline V2 & V2.1 & V2.2 & V2.3 & Y.V2 & $\bar{Y} . V 2$ \\
\hline
\end{tabular}

BIOLOGI SEL (VOL 9 NO 2 EDISI JUL-DES 2020 ISSN 2252-858X/E-ISSN 2541-1225) PAGE 194 


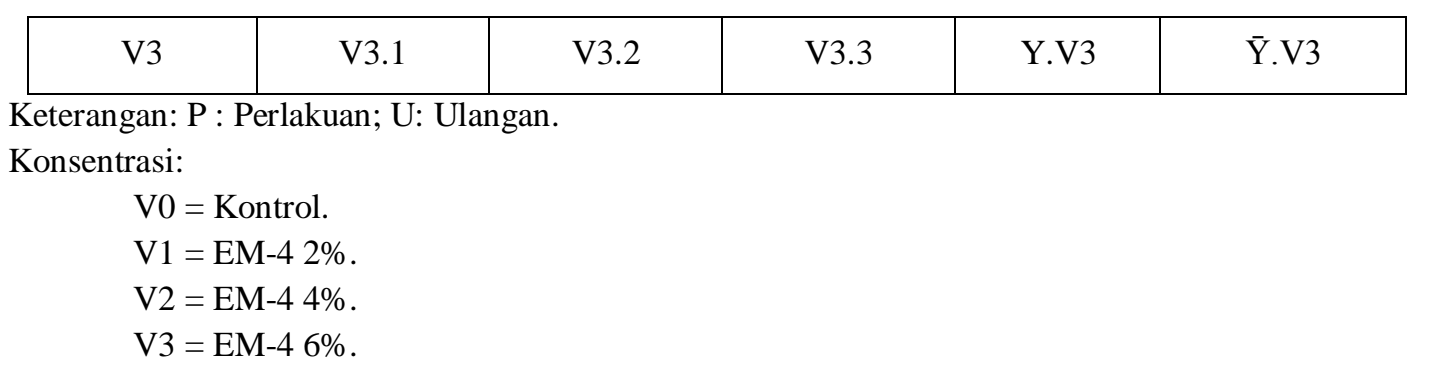

\section{Prosedur Penelitian}

Benih tanaman cabai merah yang digunakan dalam penelitian ini dibeli di salah satu tokoh pertanian yang ada di Pasar Mardika Kota Ambon, yakni dengan merek Ferosa Benih Unggul Bintang Asia.

Pemberian Efective Microorganisme (EM-4) pada limbah cair tahu akan disesuaikan dengan perlakuan atau konsentrasi yang diinginkan, yakni mulai dari perlakuan 0\% (tanpa EM-4 / kontrol), EM-4 2\%, EM-4 4\%, dan EM-4 6\%. Setelah memberi EM-4 pada limbah cair tahu, selanjutnya akan diaduk hingga merata. Cairan limbah cair tahu yang telah diberi EM-4 disimpan selama seminggu (7 hari) sebelum diberikan pada tanaman di masing-masing polybag sesuai perlakuan dengan volume 100 ml pada setiap polybag. Polybag yang digunakan berukuran $20 \times 30 \mathrm{~cm}$ dengan berat $\operatorname{tanah} \pm 2 \mathrm{~kg}$.

Bibit yang telah berumur dua minggu atau 14 hari setelah semai dengan jumlah daun 2-3 helai, dipindahkan ke kantong polybag perlakuan yang berisi media yang sesuai perlakuan. Bibit yang akan ditanam dipilih yang sehat dan berukuran seragam. Pemupukan dilakukan menggunakan limbah cair tahu yang telah diberi EM-4 yang telah jadi dan sesuai masing-masing perlakuan.

Pengamatan dilakukan setiap satu minggu, dimulai ketika tanaman baru berumur 1 minggu setelah tanam (MST), dan berakhir ketika tanaman cabai merah berumur 8 minggu setelah tanam (MST). Artinya peneliti melakukan pengamatan sebanyak 4 kali selama penelitian. Adapun parameter pengamatan yang diamati dalam penelitian ini adalah:

1. Tinggi tanaman $(\mathrm{cm})$, diukur dari permukaan tanah sampai titik tumbuh tanaman yang dilakukan setiap satu minggu sekali dengan menggunakan mistar.

2. Jumlah daun (helai), dihitung jumlah daun yang telah membuka sempurna dan dilakukan setiap satu minggu sekali.

3. Diameter batang $(\mathrm{cm})$, diukur dengan menggunakan jangka sorong pada pangkal akar di atas permukaan tanah ( $\pm 5 \mathrm{~cm}$ dari permukaan tanah) dan dilakukan setiap satu minggu sekali.

Untuk mengetahui pengaruh pemberian EM-4 (Effective Microorganisme) pada limbah cair tahu terhadap pertumbuhan tanaman cabai merah (Capsicum annuum L.), maka data hasil penelitian yang diperoleh dari penelitian akan dianalisis data dengan 
menggunakan uji F (Analisis Of Varian/ANOVA) pada taraf signifikan 5\%. Apabila pada ANOVA menunjukan perbedaan yang signifikan pada taraf 5\%, maka dilakukan uji lanjutan dengan menggunakan uji Beda Nyata Terkecil (BNT) dengan taraf signifikan 5\% untuk mengetahui derajat beda antara kelompok perlakuan (Sudjana, 1992)

\section{HASIL DAN PEMBAHASAN}

Hasil penelitian pengaruh pemberian EM-4 pada limbah cair tahu terhadap pertumbuhan tanaman cabai merah (Capsicum annuum L.) adalah sebagai berikut.

\section{Tinggi Tanaman}

Hasil penelitian tinggi tanaman cabai merah (Capsicum annuиm L.) pada berbagai perlakuan pemberian EM-4 pada limbah cair tahu disajikan pada diagram berikut.

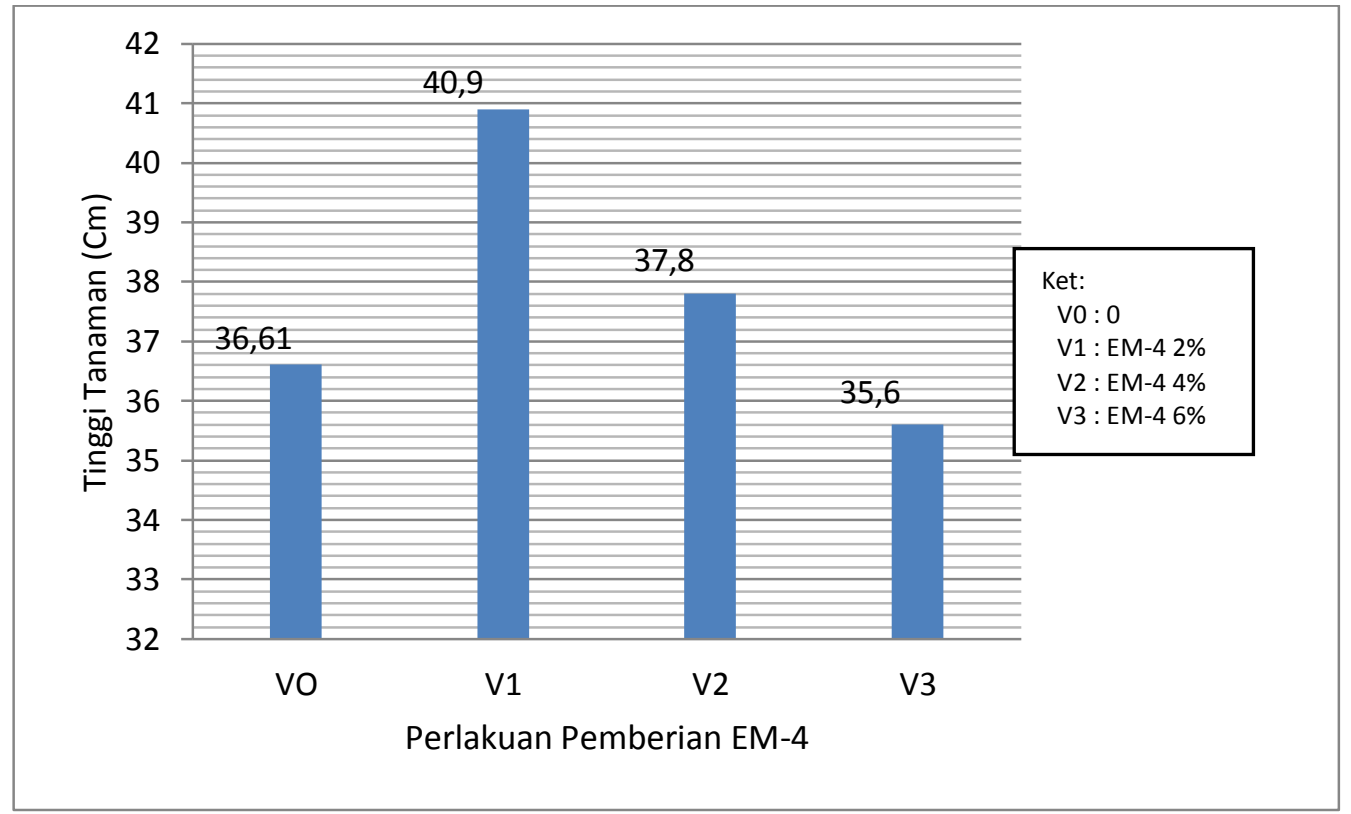

Gambar 1. Rata-rata Tinggi Tanaman Cabai Merah (Capsicum annuum L.)

Gambar di atas menunjukkan bahwa secara deskriptif rata-rata tinggi tanaman tertinggi terdapat pada perlakuan $\mathrm{V}_{1}(\mathrm{EM}-42 \%)$, yakni, $40,9 \mathrm{~cm}$, sedangkan nilai ratarata terendah berada pada perlakuan $\mathrm{V}_{3}(\mathrm{EM}-4$ 6\%) yakni dengan nilai $35,6 \mathrm{~cm}$.

Berdasarkan hasil penelitian menunjukkan bahwa secara deskriptif rata-rata tinggi tanaman tertinggi ditemukan pada perlakuan $\mathrm{V}_{1}$ dengan konsentrasi pemberian EM-4 sebesar 2\%, dengan nilai rata-rata tinggi tanaman cabai merah 40,9 cm. Meningkatnya tinggi tanaman cabai merah karena ketersediaan unsur fosfor $(\mathrm{P})$ dalam tanah yang telah diberi limbah cair tahu serta serapan fosfor yang baik oleh tanaman cabai merah. Unsur fosfor sebagai sumber energi yang membantu tanaman dalam perkembangan fase vegetatif. Selain itu, pada limbah cair tahu, selain unsur hara makro N, P, dan K, juga ada unsur hara mikro Fe, Zn yang tersedia dan diserap oleh tanaman untuk pertumbuhan vegetatif tanaman (Kaya. 2012). 
Pertumbuhan tinggi tanaman ditentukan berbagai faktor diantaranya kesuburan tanah, lingkungan yang sesuai dan pemeliharaan yang teratur dan tepat waktu. Pada tanah yang subur pertumbuhan tanaman akan lebih cepat dibandingkan dengan tanah yang tidak subur. Salah satu cara yang sering dilakukan untuk mempercepat pertumbuhan tanaman serta produktivitas yang tinggi adalah pemupukan. Pemupukan merupakan salah satu upaya yang dapat ditempuh dalam memaksimalkan hasil tanaman. Menurut Wijaya dalam Sriyanto, $d k k$, mengungkapkan bahwa pemupukan dilakukan sebagai upaya untuk mencukupi kebutuhan hara tanaman agar tujuan produksi dapat dicapai. Namun apabila penggunaan pupuk yang tidak bijaksana atau berlebihan dapat menimbulkan masalah bagi tanaman yang diusahakan, seperti keracunan, rentan terhadap hama dan penyakit, kualitas produksi rendah dan selain itu pula biaya produksi tinggi dan dapat menimbulkan pencemaran (Sriyanto dkk, 2015).

Pupuk adalah suatu bahan yang digunakan untuk mengubah sifat fisik, kimia atau biologi tanah sehingga menjadi lebih baik bagi pertumbuhan tanaman. Jenis pupuk sendiri jika dilihat dari senyawa penyusunnya dibagi menjadi dua yaitu pupuk organik dan pupuk anorganik. Pupuk organik adalah nama kolektif untuk semua jenis bahan organik asal tanaman dan hewan yang dapat dirombak menjadi hara tersedia bagi tanaman. Pupuk organik yang baik adalah pupuk yang mengutamakan kandungan $\mathrm{C}$-organik sehingga dapat menghasilkan nilai $\mathrm{C} / \mathrm{N}$ rasio yang rendah. Untuk pencapaian $\mathrm{C} / \mathrm{N}$ rasio serta kandungan Nitrogen $(\mathrm{N})$, Fosfor $(\mathrm{P})$ dan Kalium $(\mathrm{K})$ yang sesuai standar dapat dilakukan dengan membuat pupuk organik melalui proses dekomposisi dengan bantuan energi yang berasal dari fermentasi mikroba yang disebut Effective Microorganism (EM-4).

Permasalahan yang muncul dalam pembuatan pupuk organik dengan penambahan EM-4 yang berkualitas adalah belum banyak diketahui berapa volume penambahan EM4 dan waktu fermentasi yang tepat untuk pembuatan pupuk organik tersebut, sehingga dapat menghasilkan pupuk organik yang memenuhi standar yaitu memiliki $\mathrm{C} / \mathrm{N}$ rasio, $\mathrm{N}$, $\mathrm{P}, \mathrm{K}$, dan kadar air yang sesuai untuk petumbuhan tanaman.

\section{Diameter Batang}

Hasil penelitian diperoleh rata-rata diameter batang cabai merah (Capsicum annuиm L.) pada berbagai perlakuan pemberian EM-4 pada limbah cair tahu disajikan pada gambar berikut: 


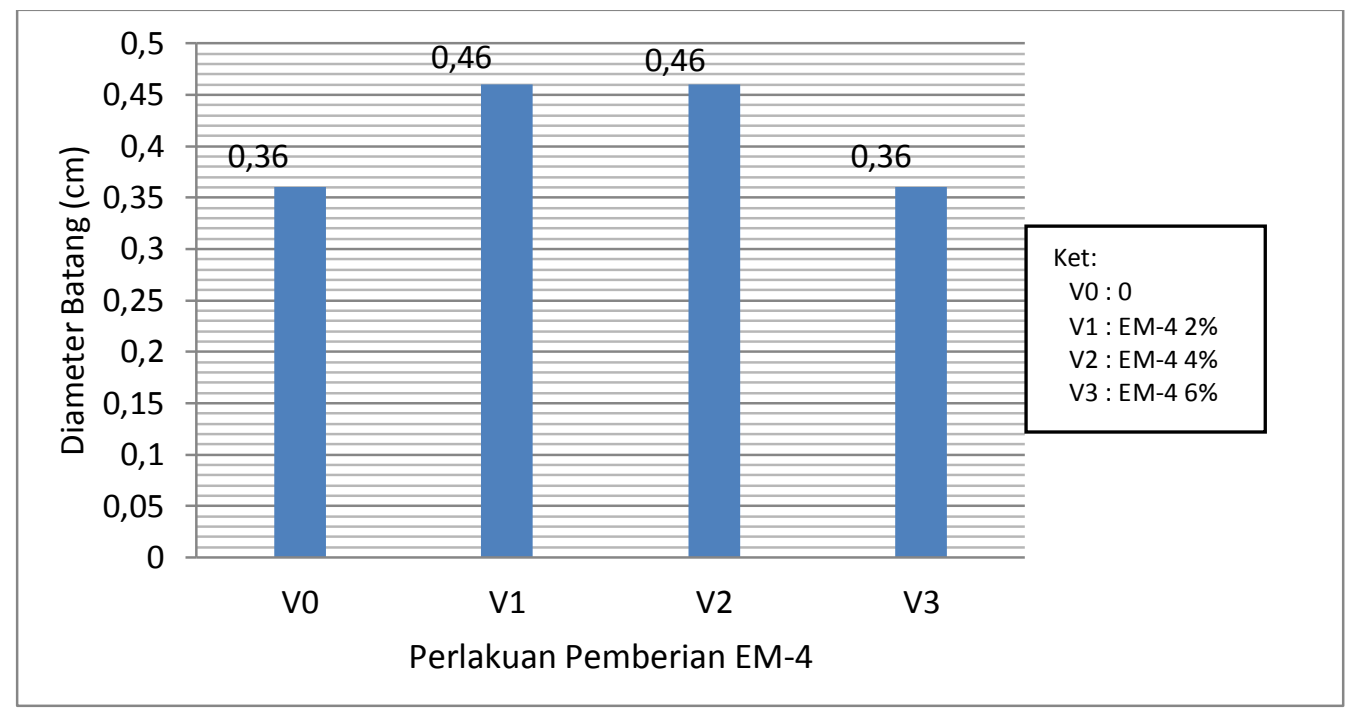

Gambar 2. Rata-rata Diameter Batang Cabai Merah (Capsicum annuum L.)

Pada Gambar 2 tersebut di atas, dapat dilihat bahwa secara deskriptif nilai ratarata diameter batang tanaman cabai merah (Capsicum annuиm L) tertinggi ada pada perlakuan $\mathrm{V}_{1}$ (EM-4 2\%), dan perlakuan $\mathrm{V}_{2}$ (EM-4 4\%) yaitu sama-sama berjumlah 0,46 $\mathrm{cm}$, sedangkan nilai rata-rata terendah berada pada perlakuan $\mathrm{V}_{0}(0)$, dan $\mathrm{V}_{3}(\mathrm{EM}-46 \%)$ yaitu sama-sama bernilai $0,36 \mathrm{~cm}$.

Secara deskriptif diketahui bahwa nilai rata-rata diameter batang tanaman cabai merah (Capsicum annuum $\mathrm{L}$ ) tertinggi ditemukan pada perlakuan $\mathrm{V}_{1}$ dengan konsentrasi EM-4 adalah 2\%, dan perlakuan $\mathrm{V}_{2}$ dengan konsentrasi EM-4 adalah $4 \%$, dimana nilai rata-rata diameter batang yaitu sama-sama berjumlah $0,46 \mathrm{~cm}$. Hal ini disebabkan karena perlakuan tersebut mampu mencukupi kebutuhan tanaman akan unsur hara. Menurut Hadisuwito dalam E. Kaya, menyatakan bahwa fungsi nitrogen $(\mathrm{N})$ adalah membentuk protein dan klorofil, fosfor $(\mathrm{P})$ berfungsi sebagai sumber energi yang membantu tanaman dalam perkembangan fase vegetatif, karbon (C) berfungsi untuk mengaktifkan pembentukan bulu-bulu akar dan menguatkan batang, kalium (K) berfungsi dalam pembentukan protein dan karbohidrat, dan sulfur (S) membantu dalam pembentukan asam amino, dan proses pertumbuhan lainnya (Kaya, 2012). Hasil penelitian ini menunjukan bahwa pada perlakuan dengan konsentrasi EM-4 sebesar 2\% adalah perlakuan terbaik untuk menyuburkan tanaman cabai merah (Capsicum annuиm L.), karena pada perlakuan pemberian EM-4 pada limbah cair tahu sebesar $2 \%\left(\mathrm{~V}_{1}\right)$ rata-rata memberian hasil yang tertinggi pada semua parameter yang diamati antara lain tinggi tanaman 40,9 cm, diameter batang 0,46 cm, dan jumlah daun 68 helai. 


\section{Jumlah Daun}

Hasil penelitian untuk rata-rata jumlah daun cabai merah (Capsicum annuиm L.) pada berbagai perlakuan pemberian EM-4 pada limbah cair tahu disajikan pada gambar berikut.

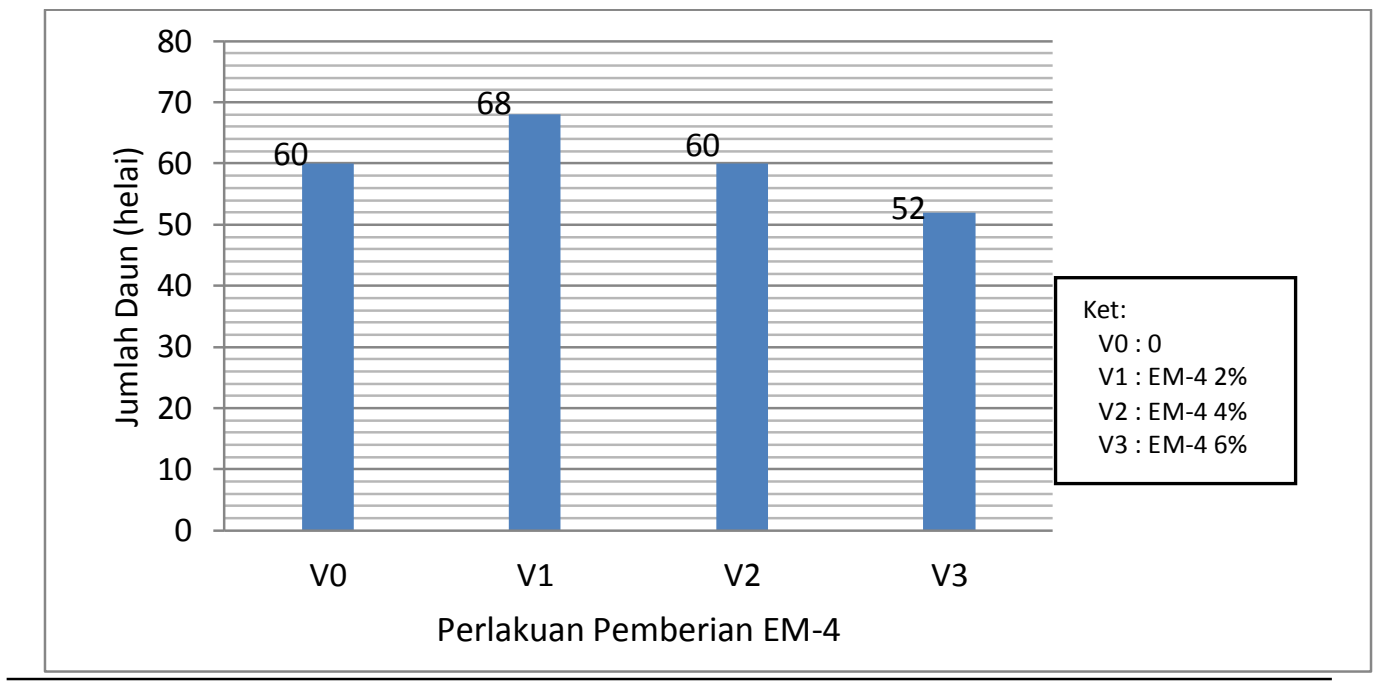

Gambar 3. Rata-Rata Jumlah Daun Cabai Merah (Capsicum annuum L.)

Gambar 3 di atas memperlihatkan bahwa secara deskriptif nilai rata-rata tertinggi untuk jumlah daun tanaman cabai merah (Capsicum annuum L) berada pada perlakuan $\mathrm{V}_{1}$ (EM-4 2\%), yakni 68 helai, sedangkan untuk nilai rata-rata terendah ada pada perlakuan $\mathrm{V}_{3}$ (EM-4 6\%), yakni 52 helai.

Daun merupakan organ tanaman yang menentukan kelangsungan hidup tanaman, karena dalam daun terjadi proses fotosintesis, respirasi dan transpirasi. Jumlah daun dan ukuran daun pada tanaman pada dasarnya dipengaruhi oleh faktor genetik dan lingkungan tumbuh tanaman tersebut. Proses pertumbuhan dan perkembangan daun dipengaruhi oleh faktor genetik dari tanaman itu sendiri sehingga dapat mempengaruhi jumlah daun, selain itu ketersediaan unsur hara juga dapat mempengaruhi jumlah daun 9oim A., 2008).

Hasil penelitian tentang jumlah daun tanaman cabai merah, diketahui bahwa secara deskriptif nilai rata-rata tertinggi untuk jumlah daun tanaman cabai merah (Capsicum annuum L) berada pada perlakuan $\mathrm{V}_{1}($ EM-4 2\%), yakni 68 helai. Dengan demikian, pemberian limbah cair tahu dengan konsentrasi EM-4 sebesar 2\% merupakan perlakuan yang lebih baik dalam meningkatkan jumlah daun tanaman cabai merah.

Hal ini diduga karena pemberian EM-4 pada limbah cair tahu dapat menyediakan unsur hara yang dibutuhkan tanaman cabai merah, khususnya unsur $\mathrm{N}$ yang sangat menentukan pada fase vegetatif terutama batang dan daun (Wardati \& Panggabena, 2015). Unsur hara yang paling berpengaruh terhadap pertumbuhan dan perkembangan daun adalah nitrogen yang berperan dalam sintesis klorofil, protein, pembentukan sel-sel baru, sehingga mampu membentuk organ-organ seperti daun. Efek kekurangan unsur $\mathrm{N}$ 
bagi tanaman antara lain pertumbuhan kerdil, warna daun menguning, produksi menurun, fase pertumbuhan terhenti dan kematian (Ardian \& Saragih, 2017).

\section{Besar Pengaruh Pemberian EM-4 pada Limbah Cair Tahu terhadap Pertumbuhan Tanaman Cabai Merah (Capsicum annuum L.)}

Berdasarkan hasil analisis varians (Anava) untuk mengetahui besarnya pengaruh pemberian EM-4 pada limbah cair tahu terhadap tinggi tanaman cabai merah (Capsicum annиuт L.) pada berbagai perlakuan menunjukkan bahwa nilai $\mathrm{F}_{\text {Hitung }}$ kelompok $(0,61)<$ $F_{\text {Tabel }}(5,14)$ dan nilai $F_{\text {Hitung perlakuan }}(1,23)<F_{\text {Tabel }}(4,76)$ pada taraf signifikan $5 \%$. Dengan demikian, dapat disimpulkan bahwa pemberian EM-4 pada limbah cair tahu memberikan pengaruh yang tidak nyata atau tidak signifikan terhadap tinggi tanaman cabai merah (Capsicum annuum L.) (Lihat Lampiran 4). Selanjutnya hasil analisis varians (Anava) pada diameter batang diperoleh nilai $\mathrm{F}_{\text {Hitung }}$ kelompok $(0,50)<\mathrm{F}_{\text {Tabel }}(5,14)$ dan nilai $\mathrm{F}_{\text {Hitung }}$ perlakuan $(3,05)<\mathrm{F}_{\text {Tabel }}(4,76)$ pada taraf signifikan 5\%. Artinya, pemberian EM-4 pada limbah cair tahu memberikan pengaruh yang tidak nyata atau tidak signifikan terhadap diameter batang tanaman cabai merah (Capsicum annuum $\mathrm{L}$ ).

Demikian pula hasil analisis sidik ragam untuk jumlah daun tanaman cabai merah (Capsicum annuum L) menunjukkan bahwa pemberian EM-4 pada limbah cair tahu memberikan pengaruh yang tidak nyata atau tidak signifikan terhadap jumlah daun tanaman cabai merah (Capsicum annuum L). Hal ini karena pada taraf signifikan $5 \%$ nilai

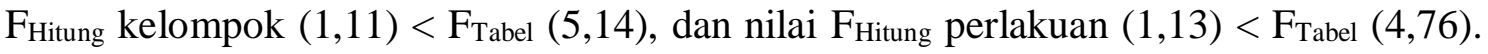
Artinya, tidak ada pengaruh pemberian EM-4 pada limbah cair tahu terhadap jumlah daun tanaman cabai merah (Capsicum annuum $\mathrm{L}$ ).

Berdasarkan analisis Anova, dapat diketahui bahwa pemberian EM-4 pada limbah cair tahu memberikan pengaruh yang tidak nyata pada taraf signifikansi 5\%. Hal ini diduga karena dengan adanya penambahan EM-4 maka jumlah mikroorganisme di dalam limbah air tahu akan semakin meningkat, namun hal ini tidak diimbangi dengan meningkatnya kapasitas dari bahan limbah cair tahu tersebut yang menyebabkan akan semakin sedikitnya ketersediaan makanan bagi mikroorganisme untuk bermetabolisme. Hal tersebut sesuai dengan pernyataan Apriwulandari, mikroorganisme memecah senyawa karbon (C) sebagai sumber energi. Hal tersebut menyebabkan terjadi kompetisi antar mikroba yang pada akhirnya akan menyebabkan matinya mikroorganisme tersebut. Sebagai indikator bahwa mikroba tersebut mati adalah tidak terjadinya proses fermentasi yang baik ditandai dengan masih tingginya kandungan C-Organik dan menurunnya suhu pada pupuk (Apriwulandari, 2008). Dengan matinya mikroba tersebut maka C-organik yang tersisa masih tinggi yang otomatis mempengaruhi meningkatnya nisbah $\mathrm{C} / \mathrm{N}$.

Hal tersebut sejalan dengan pendapat Harada dalam Abdurrohim Oim yang menyatakan bahwa keadaan limbah yang belum terdekomposisi secara baik dengan 
nisbah $\mathrm{C} / \mathrm{N}$ dan asam fenolat yang tinggi karena perlakuan tinggi, sehingga menghambat pertumbuhan tanaman. Tingginya nisbah $\mathrm{C} / \mathrm{N}$ menyebabkan mikroorganisme memerlukan energi untuk proses dekomposisi lebih lanjut. Jika bahan organik yang digunakan masih mempunyai nisbah $\mathrm{C} / \mathrm{N}$ tinggi, maka tanaman akan kekurangan nitrogen $(\mathrm{N})$ karena immobilisasi dan menghambat pertumbuhan tanaman (Oim A., 2008).

\section{KESIMPULAN}

1. Secara deskriptif terdapat pengaruh pemberian EM-4 (Effective Microorganisme) pada limbah cair tahu terhadap pertumbuhan tanaman cabai merah (Capsicum annuит L.), yakni pada perlakuan pemberian EM-4 pada limbah cair tahu sebesar 2\% $\left(\mathrm{V}_{1}\right)$ rata-rata memberian hasil yang tertinggi pada semua parameter yang diamati antara lain tinggi tanaman 40,9 cm, diameter batang 0,46 cm, dan jumlah daun 68 helai.

2. Berdasarkan analisis varian (ANOVA) tidak terdapat pengaruh pemberian EM-4 (Effective Microorganisme) pada limbah cair tahu terhadap pertumbuhan tanaman cabai merah (Capsicum annuum $\mathrm{L}$.) pada tinggi tanaman karena nilai $\mathrm{F}_{\text {Hitung }}$ kelompok $(0,61)<F_{\text {Tabel }}(5,14)$ dan nilai $F_{\text {Hitung perlakuan }(1,23)<F_{\text {Tabel }}(4,76) \text { pada taraf }}$ signifikan $5 \%$. Pada diameter batang juga tidak memberikan pengaruh yang nyata karena nilai $F_{\text {Hitung kelompok }}(0,50)<\mathrm{F}_{\text {Tabel }}(5,14)$ dan nilai $F_{\text {Hitung }}$ perlakuan $(3,05)<$ $\mathrm{F}_{\text {Tabel }}(4,76)$ pada taraf signifikan $5 \%$. Demikian juga pada jumlah daun tidak memberikan pengaruh yang nyata karena pada taraf signifikan $5 \%$ nilai $\mathrm{F}_{\text {Hitung }}$ kelompok $(1,11)<\mathrm{F}_{\text {Tabel }}(5,14)$, dan nilai $\mathrm{F}_{\text {Hitung }}$ perlakuan $(1,13)<\mathrm{F}_{\text {Tabel }}(4,76)$.

\section{SARAN}

1. Kepada petani cabai merah jika menggunakan pemberian EM-4 pada limbah cair tahu disarankan pada konsentrasi sebesar $2 \%$.

2. Kepada peneliti lainnya agar melakukan penelitian lanjutan terkait perlakuan pemberian EM-4 pada limbah cair tahu pada jenis tanaman yang berbeda.

\section{DAFTAR PUSTAKA}

Al-Amin, Ahmad., Arnis En Yulia dan Nurbaiti. (2017). Pemanfaatan Limbah Cair Tahu Untuk Pertumbuhan dan Produksi Tanaman Pakcoy (Brassica rapa L.) Jurnal JOM FAPERTA Vol. 4 No. 2. Hal. 1-8.

Apriwulandari, I. (2008). Pengaruh Pemberian Kotoran Sapi dan Pucuk Nitrogen Terhadap Sifat Kimia Tanah dan Pencucian Nitrat Serta Pertumbuhan Tanaman Jagung Manis. Skripsi. Malang: Fakultas Pertanian Universitas Brawijaya.

Departemen Pendidikan Nasional. (2002). Kamus Besar Bahasa Indonesia. Jakarta: DEPDIKNAS. 
Djuarni, N. (2005). Cara Cepat Membuat Kompos. PT. Agromedia Pustaka. Jakarta Hadiyanto, Iskandar. (2005). Bertanam Cabai. Balai Pustaka. Jakarta.

Hanafiah, Kemas Ali. (2010). Rancangan Percobaan Teori dan Aplikasi, PT Raja Grafindo Persada. Jakarta.

Kaya, E. (2012). Pengaruh Pemberian Pemberian EM-4 pada limbah cair tahu dan Pupuk ABG Bunga-Buah terhadap P-Tersedia, serapan-P, serta Pertumbuhan Tanaman Jagung (Zea mays L.) pada inceptisols. Jurnal Penelitian. Universitas Pattimura Ambon.

Martodireso, Sudadi dan Widada Agus Suryanto. (2011). Terobosan Teknologi Pemupukan Dalam Era Pertanian Organik. Cet.VII: Kanisius. Yoyakarta

Oim, Abdurrohim. (2008). Pengaruh Kompos Terhadap Ketersediaan Hara dan Produksi Tanaman Caisin pada Tanah Latosol Drai Gunung Sindur. Skripsi. Bogor: Institut Pertanian Bogor.

Panggabean, Putra dan Wardati. (2015). Pengaruh Pupuk Organik Cair Dan Pupuk Kompos Kulit Buah Kakao Terhadap Pertumbuhan Bibit Kelapa Sawit (Elaeis gueneensis Jacq.) di Pembibitan Utama. Jurnal JOM FAPERTA. Vol. 2 No. 2. Hal. 25-38.

Prajanata, Final. (2007). Kiat Sukses Bertanam Cabai Di Musim Hujan. Cet.XII Penebar Swadaya. Jakarta:

Saragih, Doni Pasdo dan Ardian. (2017). Pengaruh Pemberian Kompos Kulit Buah Kakao Terhadap Pertumbuhan Bibit Kakao Hibrida (Theobroma cacao L.). Jurnal JOM FAPERTA. Vol. 4, No. 2, Hal. 12-24.

Siswati, Nana Dyah., Herwindo Theodorus dan Puguh Wahyu Eko S. (2009). Kajian Penambahan Effective Microorganisms (EM4) pada Proses Dekomposisi Limbah Padat Industri Kertas. Jurnal Buana Sains. Vol 9, No. 1, Hal. 67-88).

Sriyanto, Doni., dkk. (2015). Pengaruh Dosis Pupuk Kandang Sapi Terhadap Pertumbuhan Dan Hasil Tanaman Terung Ungu dan Terung Hijau (Solanum melongena L.). Jurnal AGRIFOR. Vol. XIV, No. 1, Hal. 45-60.

Subekti, S. (2011). Pengolahan Limbah Cair Tahu Menjadi Biogas sebagai Bahan Bakar Alternatif. Skripsi. Semarang: Program Studi Ilmu Lingkungan, Universitas Padjajaran.

Sudjana, Arman. (2007). Kamus Lengkap Biologi. Mega Aksara. Jakarta.

Sudjana. (1992). Metode Statistik. Tarsito. Bandung.

Sumiati, Etty., dan Herbagiandono. (1995). Pengaruh beberapa Zat Pengatur Tumbuh dan Pupuk Daun Biokimia Terhadap Hasil Buah Cabe (Capsicum annuum L.) Kultifar Padang. Bul. Panel. Hort. Vol. XII, No. 1.

Sunaryono, H. (2002). Budidaya Cabai Merah. Sinar Baru Algensindo. Bandung. 
Umniyatie, dkk. (1999). Pembuatan Pupuk Organik Menggunakan Mikroba Efektif (Effective Microorganisms 4). Laporan PPM UNY: Karya Alternatif Mahasiswa, 1999).

Wiryanta, Bernadinus T.W. (2001). Bertanam Cabai Pada Musim Hujan. PT. Agromedia Pustaka. Jakarta 